\title{
Optimal Conversion of Forest Land to Agriculture: Evidence from Côte d'Ivoire
}

\author{
Wadjamsse Beaudelaire DJEZOU \\ Assistant Professor at the University of Bouaké and Researcher, \\ Ivorian Center for Economic and Social Research (CIRES) \\ 08 P.O. Box 1295 Abidjan 08 (Côte d'Ivoire) \\ E-mail: wdjezou2000@yahoo.fr
}

Received: April 11, 2013 Accepted: April 29, 2013

doi:10.5296/jas.v1i2.3938ＵRL: http://dx.doi.org/10.5296/jas.v1i2.3938

\begin{abstract}
The Ivorian economy is based on agriculture which constitutes by far the main cause of deforestation through its shifting characteristic. This situation threatens the ecological equilibrium on which depends in turn agricultural productivity.

This paper investigates the determinants for optimal conversion of forest land to agriculture. To this end, we firstly established the optimal rule of forest land allocation to agriculture based on a rigorous forest land use modelling using optimal control techniques. Secondly, we evaluate the effects of the variables highlighted by the theoretical model through an econometric model in the form of error correction model. The study shows that the opportunity cost of forest land and the marginal cost of agricultural exploitation preserve the forest by limiting forest land conversion to agriculture. However, a technological progress in agricultural sector amplifies land conversion process. Finally, we found that there is a minimum level of agricultural yield $(967.1 \mathrm{~kg} / \mathrm{ha})$ required to reduce forest land conversion. Thus, the paper recommends the development of off farm activities, an increase in agricultural yield and the adoption of labour intensive technologies in order to ensure a sustainable economic growth.
\end{abstract}

Keywords: Agriculture, Forest land allocation model, Deforestation, Optimal control, Opportunity cost

\section{Introduction}

The economy of Côte d'Ivoire is based on agriculture. This sector represented in average about $30 \%$ of its GDP from 2000 to 2010, 75\% of non-oil export revenues and employed $46 \%$ of 
working population (Ministry of Planning and Development, 2012). Indeed, $70 \%$ of the total surface of the country can be potentially used for agriculture (Coulibaly, 1998).

The production of crops like rice, yam, plantain, cassava and corn, has increased on average by $2.4 \%$ per year since 1990. It was estimated to 8.9 million tons in 1999 and employed more than 2300000 persons for a surface of 2448000 ha. It represented in value 1084 billion Fcfa ${ }^{1}$ which was $11.4 \%$ of the GDP in 1999 (MINEF, 2007). From one crop to another, the annual total production expressed in tons of products increased. However, this growth was not the fact of productivity gain but it was closely related to the increase in the agricultural surface (graph 1a and $1 \mathrm{~b}$ bellow) and the number of workers (FOSA, 2001). Indeed, the Ivorian agriculture which is the pillar of the economy especially with its main export crops (coffee and cocoa), constitutes by far the large devourer of forest land as generally noted in similar studies in tropical forest (Barbier, 1997; Benhin, 2006). More precisely, in 1997, 7.5 million hectares were conquered by agriculture representing 975 million tons of wood destroyed against 300 million cubic meter of timber exploited between 1960 and 1980 (Mercier, 1991). In the same way, the fall in the international price of the exports products in 1980, the low agricultural yields compared to those of 1960, and the demographic pressure led to the abusive extension of agricultural surfaces to the detriment of forest cover as mentioned in other country case studies (Barbier and Burgess, 2001; Barbier, 2004; Von Braun, 2007; Shandra et al., 2008). This situation is partly explained by the practice of shifting agriculture and fallow systems by farmers. Indeed, these agricultural practices require the use of a large amount of new arable land every year and compromise in turn the agricultural productivity in the long run. In addition, the weak progression of land occupation by agriculture since 1989 indicates partly the problem of land saturation. Indeed, in 1997, 23.25\% of the national territory were in crops (World Resources, 2000-2001) against 20.2\% in 1993, 23\% in 1989, 11\% in 1975, 6\% in 1965 and $3.5 \%$ in 1960 (National Plan of Environmental Action, 1996). As a result, the infiltrations in protected forest for agricultural activities have increased. The rate of this agricultural infiltration reached $26 \%$ in 1999. West and Western South regions of the country had the highest rates of infiltration which was approximately $24 \%$ and $44 \%$ respectively (Sodefor, 1994).

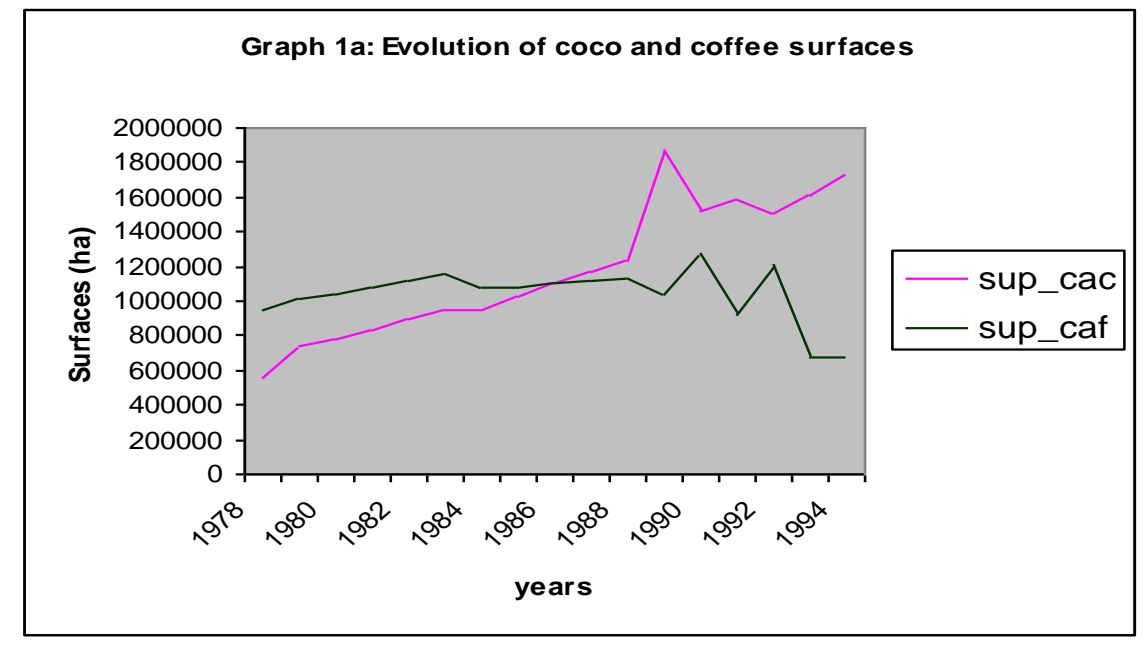

\footnotetext{
${ }^{1}$ Fcfa is the currency used by West African Economic and Monetary Union (WAEMU) countries.
} 


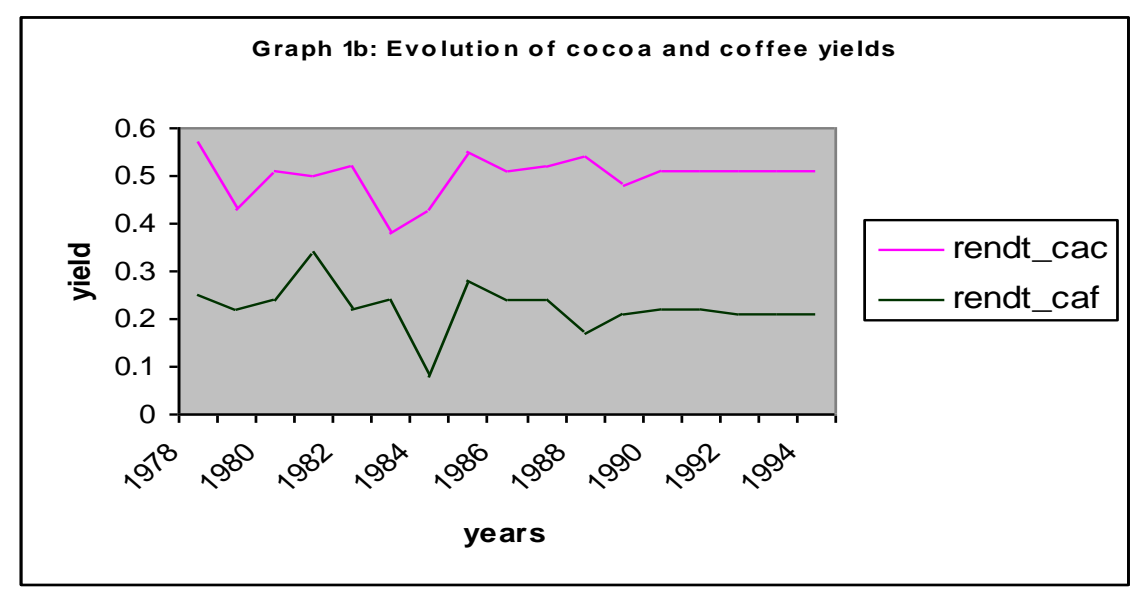

Figure 1. Author using data from agricultural statistics 2004 of the Ministry of agriculture of Côte d'Ivoire

It comes from these observations that agricultural production and forest conservation are negatively related as noted by various authors (Barbier, 1997; Perman et al., 2003; Matson \& Vitousek, 2006; Behnin, 2006). This situation raises the following question: do increases in agricultural production compatible with forest conservation? In other words, how to balance increasing agriculture production and forest conservation?

Many studies have been undertaken across countries to determine the factors that lead to deforestation considering macro level variables and ad hoc approach (Barbier \& Burgess, 1997; Arcand et al., 2008; Ewers et al., 2009; Gibbs et al., 2010; Phalan B. et al., 2013) and lead often to serious misspecification in regression models (Angelsen \& Kaimowitz, 1999, Damette \& Delacote, 2012). According to Barbier (2001) and Pender J. et al. (2003), the efficient strategies to increase agricultural production and control deforestation must be location-specific. Indeed, country case studies are able to investigate in much more detail other key factors that influence the economics of tropical deforestation and land use.

Based on these critics, we develop a theoretical model for land allocation between agriculture, forest exploitation for timber and forest conservation in Côte d'Ivoire and derive econometric model.

The main objective of this paper is to investigate the determinants of the optimal conversion of the forest land to agriculture. In a specific way, we:

- establish a rule of optimal conversion of forest land to agriculture.

-evaluate the effects of the determining factors of this forest land conversion to agriculture.

- propose some policy recommendations.

The rest of the paper is organized as follows: section 2 presents the literature review on the relationship between agriculture and deforestation. The section 3 develops the theoretical model for optimal land allocation in Côte d'Ivoire, specifies an econometric model. The section 4 analyses and discusses the results. The last section concludes the study by formulating some recommendations to drive the country along the socially optimal 
deforestation path.

\section{Literature Review}

An important area of economic research into tropical deforestation consists of cross-country, regional, and selective country-level statistical analyses of the factors determining declining forest cover. These surveys suggest that the following key factors have an important influence on tropical deforestation both within and across countries: income; population growth/density; agricultural prices/returns; agricultural yields; agricultural exports/export share; logging prices/returns/production; roads and road building; scale factors (size of forest stock, land area, etc.); and institutional factors (political stability, property rights, rule of law, etc.).

Most of these approaches to cross-country analyses have a tendency to be ad hoc and rely mainly on macro level variables. They used to put all variables mentioned above in a single equation. As a result, the relationship between deforestation and multiple causative factors are many and varied, showing no distinct pattern. According to Angelsen and Kaimowitz (1999), the mixing up of these three levels of deforestation distorts the causal relationship and often leads to serious misspecification in regression models. Furthermore, potential statistical problems of multicollinearity and biased estimates may be encountered.

However, not all studies suffer from an ad hoc approach to cross-country analysis. In recent years, there have been a number of studies that have attempted to develop a specific model or approach to explaining deforestation, and then have tested the resulting hypothesis. Firstly, there are competing land use models. In these models, the empirical analyses took as their starting point the hypothesis that forest loss in tropical countries is the result of competing land use, in particular between maintaining the natural forest and agriculture (Ehui and Hertel 1989; Barbier and Burgess 1997). Secondly, there are forest land conversion models. Many country-level studies of tropical deforestation have focused on the forest land conversion decision of agricultural households (Panayotou and Sungsuwan, 1994; Barbier and Burgess 1996; Chomitz and Gray 1996; Nelson and Hellerstein 1996; Lopez 1997; Cropper, Griffiths, and Mani 1999; Barbier 2000 ; Adu et al., 2012). Such approaches model the derived demand for converted land by rural smallholders, and assume that the households either use available labor to convert their own land or purchase it from a market. This in turn allows the determinants of the equilibrium level of converted land to be specified. In such models, the aggregate equilibrium level of cleared land across all households is usually hypothesized to be a function of output and input prices and other factors affecting aggregate conversion. All these approaches lead to a various results.

Studies for representative countries in Asia, Africa, and Latin America have tended to confirm that agricultural conversion is positively related to agricultural output prices and decreases with rural wage rates (Barbier and Burgess, 1996; Lopez, 1997; Barbier, 2000). Barbier and Burgess (1996) analyzing the main factors affecting forest land conversion in Mexico between 1970-1985 found that maize and fertiliser prices appeared to be the main influences on the expansion of planted area. Based on the market theoretical approach, Angelsen et al (1999) statistical analysis in Tanzania showed that the increase in agricultural output prices, in particular annual crops is a major factor behind deforestation. Furthermore, the results of these 
authors were confirmed in Côte d'Ivoire where the effects of price increase of export goods contributed to deforestation (Reed, 1992). Similarly, Osei Asare and Obeng Asiedu (2000) found in Ghana that higher levels of fertiliser prices, food crop prices and coffee producer prices stimulate in the long-run higher levels of deforestation whereas higher levels of agricultural wages precipitates lower levels of deforestation. Delacote (2009) also confirms these results.

In addition, agricultural productivity matters. Some authors like Bashaasha, Kraybill, and Southgate(2001) using CGE model conclude that improvements in agricultural productivity and overall development across Uganda are more effective approaches to mitigating deforestation than either targeting improvements to specific agricultural sectors or implementing a fuelwood tax. Indeed, increasing agricultural productivity and input use reflect greater agricultural intensification and development, which in turn mean less pressure is put on conversion of forests and other marginal lands for use in agriculture (Barbier, 1997). Likewise, agricultural value added is positively associated with agricultural land expansion (Barbier, 2004). These findings are in line with the MA (market approach) for which agricultural production and land use are determined by the relative profitability of agriculture, and not by any population requirement.

Technological progress has ambiguous effects. According to Cattaneo (2001) who developed a CGE model to assess the impacts on deforestation in the Brazilian Amazon, the impacts of technological change depend on the sector. Thus, in the annual crops sector, deforestation increases and in the perennial crops sector, it will reduce.

In other respects, lower log prices reduce the profitability of forestry and hence encourage the conversion of forestlands to other uses such as agriculture (Brandon and Ramankutty 1993; and Sharma et al. 1994).

Moreover, in recent years, a variety of empirical analyses at both the country and cross-country level have explored the impact on tropical deforestation of institutional factors, such as land use conflict, security of ownership or property rights, political stability, and the "rule of law" (Deacon 1994/1999; Godoy et al., 1998; Alston, Libecap \& Mueller, 1999/2000). The main hypothesis tested is that such institutional factors are important factors explaining deforestation. Deacon (1999) showed that the main institutional variable (ownership security) proved to be significant and positive in all models suggesting that greater security reduces forest loss. In the same way, Cattameo (Op. cit) found that within the Amazon, improving land tenure security would reduce deforestation significantly, although implementing this policy in the frontier region would be extremely difficult. Similarly, Reed (1992) pointed out the lack of a consistent and secure land tenure system as the main factor of deforestation in Côte d'Ivoire.

Although the land conversion model appears to work well for specific tropical forest countries, it is difficult to obtain time series data on agricultural input and output prices (especially rural wage rates) for many tropical countries. The worse thing is that indices on political stability, corruption, ownership security, and other institutional factors that are available for tropical countries tend not to vary much over time, or are constructed as averages over long time periods. Thus the inclusion of institutional indices means the use of a time-invariant variable in 
a panel analysis explaining forest loss in only a representative sample of tropical countries.

As noted by Barbier (2001), country case studies are able to investigate in much more detail other key factors that influence the economics of tropical deforestation and land use. Therefore, this paper stands on three motivations. Firstly, as deforestation is a location specific problem with the effect and magnitude of each identified factor differing from country to country and from one region to another, it is absolutely necessary to highlight the factors that explain forest conversion in Côte d'Ivoire through a country specific theoretical model. Secondly, we empirically determine the extent and the degree to which the immediate factors identified influence the progressive conversion of forest land to agriculture. Thirdly, given that a mixing up of the various levels of factors causing deforestation leads to a wrong specification of causal relationship between variables, this paper avoids this type of mistake by concentrating on immediate causes of conversion of forests at micro level and not at macro level as did in previous studies. This is because the immediate causes have a direct effect on the disappearance of forests compared to the underlying causes. They determine the major decisions that farmers and loggers make about the area to be cleared for agriculture and logging. This would help in the formulation of appropriate economic, agricultural and environmental policies to mitigate, if not halt the effects of unsustainable conversion of forests.

\section{Methodology}

We successively present theoretical model and empirical model of forest land conversion.

\subsection{Intertemporal Model for Allocation of Forest Land}

\subsubsection{Model Formulation}

We set up our model of land allocation in the form of optimal control model. We consider three competing uses of land which are land for agriculture $x_{1, t}$, land for timber $x_{2, t}$ and land for forest conservation $x_{3, t}$. We also introduce the afforestation/reforestation $x_{4, t}$ in the model which comes with a cost $C\left(x_{4, t}\right)$. All these land area are measured in hectares. Let's $w_{t}$ be the total land area for these various uses. If $w_{t}$ is the total land area, the change in total available land for the various uses is given by this equation:

$$
w_{t}-w_{t-1}=x_{4, t}+x_{3, t}-x_{2, t}-x_{1, t}
$$

As shown by the equation (1), the total land area available for various current uses is positively affected by forest preservation (forest stock and afforestation/reforestation) while agriculture and timber exploitation surfaces negatively affect it.

In addition, we introduce the interaction or land transfers between land use options by accounting for their endogenous growth in time. Thus, change in agricultural surface each 
period depends both on agricultural surface and forest surface harvested for timber the previous period. Indeed, according to Coulibaly (1998), farmers reconvert previous agricultural surface $x_{1, t-1}$ into agricultural land the following year at a given constant rate $\alpha_{1}$ with $0 \leq \alpha_{1} \leq 1$. In the same way, the surface of forest exploited for timber the previous year $x_{2, t-1}$ is converted to agricultural land the following year at a given constant rate $\alpha_{2}$ with $0 \leq \alpha_{2} \leq 1$. This is to account for the agricultural land expansion due to timber exploitation. Indeed, farmers generally use roads made by timber harvesters to infiltrate the forest area and develop their crops (Karsenty et al, 1994). Thus, the agricultural land at a given period $t$ is depicted by the following expression:

$x_{1, t}=\alpha_{1} x_{1, t-1}+\alpha_{2} x_{2, t-1}$

This expression can be rewritten as follows:

$$
x_{1, t}-\alpha_{1} x_{1, t-1}=\alpha_{2} x_{2, t-1}
$$

Moreover, the change in forest stock $x_{3, t}$ (conservation purpose) depends both on the natural rate of forest regeneration $\beta(0 \leq \beta \leq 1)$ after timber exploitation and the surface reforested or afforested by the government the previous year $x_{4, t-1}$ according to the following equation:

$$
x_{3, t}-x_{3, t-1}=x_{4, t-1}+(\beta-1) x_{2, t-1}
$$

It may difficult to accept that one year old reforested or afforested land is a forest but we consider that once the area is reforested (or afforested), the zone is monitored and managed such that it will become absolutely forest plot in the next coming years.

Finally, we consider a benevolent social planner who wishes to maximize the discounted value of the stream of profits $R_{i}\left(x_{i, t}\right)$ (with $i=1,2,3$ ) deriving from the various land use options over the time horizon under some constraints including the ecological constraint given in equation (4). This constraint ensures that agro-ecological conditions are maintained.

$$
x_{3, t}-\alpha_{0} w_{t} \geq 0
$$

The ecological constraint states that the surface maintained in forest should be at least $\alpha_{0} \%$ of the country area (here we consider total land area). 


\section{IIMacrothink}

Journal of Agricultural Studies

ISSN 2166-0379 2013, Vol. 1, No. 2

The model in the form of dynamic optimization programme in discrete time can be presented as follows:

$$
\underbrace{\operatorname{Max}}_{x_{1, t}, x_{2, t}, x_{3, t}, x_{4}, t} \sum_{t=1}^{T} \frac{1}{\left(1+r_{0}\right)^{t-1}}\left[R_{1}\left(x_{1, t}\right)+R_{2}\left(x_{2, t}\right)+R_{3}\left(x_{3, t}\right)-C\left(x_{4, t}\right)\right]
$$

Subject to:

$$
\begin{gathered}
w_{t}-w_{t-1}=x_{4, t}+x_{3, t}-x_{2, t}-x_{1, t} \\
x_{1, t}-\alpha_{1} x_{1, t-1}=\alpha_{2} x_{2, t-1} \\
x_{3, t}-x_{3, t-1}=x_{4, t-1}+(\beta-1) x_{2, t-1} \\
x_{3, t}-\alpha_{0} w_{t} \geq 0 \\
w_{0}=w(0), x_{1,0}=x_{1,0}(0), x_{3,0}=x_{3,0}(0) \\
x_{1, t}, x_{2, t}, x_{3, t}, x_{4, t} \geq 0
\end{gathered}
$$

Where $r_{0}$ is the social discount rate.

The discount factor is $1 /\left(1+r_{0}\right)^{t-1}$.

$R_{1}\left(x_{1, t}\right)$ is the profit deriving from agricultural activity on surface $x_{1, t}$ at any period t.

$R_{2}\left(x_{2, t}\right)$ is the profit deriving from timber production on surface $x_{2, t}$ at any period t.

$R_{3}\left(x_{3, t}\right)$ is the instantaneous value (benefit) of the forest capitalized on surface $x_{3, t}$ at the social discount rate $\mathrm{t}$.

$C\left(x_{4 t}\right)$ is the instantaneous cost of the afforestation/reforestation activity on a surface $x_{4, t}$.

Equation (5) is the discounted social profit function. Equation (6) presents initial conditions. Equation (7) states non negativity conditions. 
We solve the problem by using lagrangean method. For a question of fluidity, the details of the resolution (lagrangean formulation, first and second order conditions, initial conditions, binding conditions, transversality conditions and excluding relations) are presented in appendix 1 and the results are discussed here in the following sub section.

\subsubsection{Results and Interpretations}

We establish an optimal allocation between land for timber exploitation, agricultural land and land for forest conservation and afforestation in order to formulate sustainable management policies for the tropical forest. In particular, we derive from this model an optimal agricultural land expansion equation.

From equations (23)-(25) in appendix, we consider two cases according to whether ecological balance is threatened or not i.e whether the marginal profit of forest resource $\left(\omega_{t}\right)$ is greater or equal to zero.

\section{$\checkmark$ First case $\omega_{t}=0$}

This assumption states that any variation in the ecological constraint does not have any effect on the objective function at its maximum. Indeed, the loss or the preservation of an additional unit of forest land does not affect the social welfare. Thus, national forest cover is not threatened and the ecological constraint can be largely satisfied.

Equations (13) and (24) lead to:

$$
\lambda_{1, t+1}-\lambda_{1, t}=\lambda_{1, t}-\lambda_{1, t+1} \Rightarrow 2\left(\lambda_{1, t+1}-\lambda_{1, t}\right)=0 \Rightarrow \lambda_{1, t+1}=\lambda_{1, t} \forall t
$$

On the basis of equation (26) and considering equations (9) and (13) in appendix 1, we have

$$
\frac{R_{1}^{\prime}\left(x_{1 t}^{*}\right)}{\left(1+r_{0}\right)^{t-1}}=\lambda_{1, t}^{*}+\left(1-\alpha_{1}\right) \lambda_{2, t}^{*}
$$

Equation [27] establishes the optimal allocation rule of forest land conversion to agriculture. Indeed, the optimal rate at which the forest land should be converted to agriculture corresponds to the maximum benefice deriving from this activity after accounting for social opportunity cost. This cost comprises: the private cost (set to zero in this study), the user cost and the cost of externality. In other words, this optimal rate corresponds to the point where social marginal benefice equates social marginal opportunity cost. Thus, forest land is converted to agriculture up to the point where the discounted marginal benefits of agriculture are equal to its discounted marginal social opportunity costs. These costs are the marginal user cost of forest land $\left(\lambda_{1, t}^{*}\right)$ and the marginal cost of damage (externality in the form of abandoned agricultural land) $\left(1-\alpha_{1}\right) \lambda_{2, t}^{*}$ which is evaluated at the shadow value of agricultural land $\left(\lambda_{2, t}^{*}\right)$. This opportunity cost is the maximum forgone marginal benefice that could have been obtained elsewhere from 
the unit of land converted to agriculture.

The marginal social opportunity cost is a decreasing function of the reconversion rate of agricultural surface. The more the previous agricultural surface is converted to the current use the less the social marginal opportunity cost is and vice versa. In other words, the higher the rate of abandoned land for new ones the higher the social marginal opportunity cost is. If farmers pay the real price (shadow price) of forest land they will reduce, ceteris paribus, their demand on the basis of the demand theory in the context of normal good where price (shadow price) and quantity are inversely related. Unfortunately, many of these environmental benefits have no market and thus are generally ignored in private and public land use decisions (Adu et al., 2012). However, the social opportunity cost of converting the forest land to agriculture ought to reflect both its value for marketed production as well as non-marketed environmental net benefits.

\section{$\checkmark$ Second case: $\omega_{t}>0$,}

This assumption states that any change in the ecological constraint significantly affects the objective function at its maximum. Indeed, the loss or the preservation of an additional unit of forest land affects the social welfare. Thus, national forest cover is threatened and the ecological constraint is questioned.

On this basis equation [13] becomes:

$$
2\left(\lambda_{1, t+1}-\lambda_{1, t}\right)=\alpha_{0} \omega_{t} \Rightarrow \lambda_{1, t+1}>\lambda_{1, t}, \quad \forall t
$$

The results obtained in the previous case (first case) are modified as follows:

The major changes that the modification of the ecological constraint involves are the continuous decrease in optimal agricultural surfaces, optimal timber production surfaces and optimal energy production surfaces from period to period. On the contrary, the optimal stock of forest has to grow from period to period with the intensification of reforestation activity since the preservation of an additional unit of forest positively affects the social welfare. Practically, if we consider that the benefit function is concave then any increase in the marginal benefit or income can be done only with a reduction in the variable. For example, at the period $t+1$, equation [27] becomes $\frac{R_{1}^{\prime}\left(x_{1 t+1}^{*}\right)}{\left(1+r_{0}\right)^{t}}=\lambda_{1, t+1}^{*}+\left(1-\alpha_{1}\right) \lambda_{2, t}^{*}$ and $x_{1 t+1}^{*}<x_{1 t}^{*}, \forall t$ since $\lambda_{1, t+1}^{*}>\lambda_{1, t}^{*}$.

\subsection{Empirical Specification of Optimal Conversion of Forest Land}

\subsubsection{Econometric Model Specification}

The optimal allocation of tropical forests between competing uses essentially determines the price of land. That is, land values are determined by discounted future rental values. Therefore, equation [27] is the inverse demand function of converting forest land to agriculture since it represents the equilibrium shadow price of farm land conversion. This inverse demand 
function is the demand function viewing price as a function of quantity and can be rewritten as $p_{t}^{a}=\lambda_{1, t}^{*}+\left(1-\alpha_{1}\right) \lambda_{2, t}^{*}=\lambda_{1, t}^{*}+\lambda_{2, t}^{*}-\alpha_{1} \lambda_{2, t}^{*}$ with $p_{t}^{a}=D_{t}^{-1}\left(x_{1 t}\right)$ where $p_{t}^{a}$ is the discounted marginal benefice of forest land conversion to agriculture. This means that the price of agricultural land conversion is measuring the marginal willingness to pay. In fact, for any optimal level of converting forest land to agriculture, the inverse demand function tells how much the consumer or decision maker would willing to sacrifice the alternative use of forest land to make him just indifferent to having a little more of farm land. From this inverse demand function, one can get the (direct) demand function for converting forest land to agriculture as $x_{1 t}=D_{t}\left(p_{t}^{a}\right)=D_{t}\left(\lambda_{1, t}^{*}, \lambda_{2, t}^{*}, \theta_{t}^{*}\right)$ where $\theta_{t}^{*}=\alpha_{1} \lambda_{2, t}^{*}$ which is the gain associated to agricultural land reconversion. Contrary to our intertemporal model of allocation of forest land (theoretical model above) where we set marginal cost of agricultural production to zero, we will consider non zero marginal cost $(\mathrm{mc})$ in the empirical specification model. The last and only thing we include in the empirical specification of the model is the technological progress variable (tech) as exogenous control variable. Our objective is to explain forest land conversion to farmland by its direct causes (Delacote, 2009) highlighted by our theoretical model. Finally, our empirical demand for converting forest land to agriculture is specified as follows:

$$
x_{1 t}=D_{t}\left(\lambda_{1, t}^{*}, \lambda_{2, t}^{*}, \theta_{t}^{*}, m c_{t}, \text { tech }_{t}\right)
$$

Where $x_{1 t}$ is the quantity of forest land converted to agriculture. We use in this study the agricultural surface $\left(a g r s_{t}\right)$ as a proxy of forest land converted to agriculture. As the opportunity costs of choosing agricultural use option is foregoing the net benefits of alternative uses especially timber benefit, we use roundwood export $\left(r w d_{t}\right)$ as a proxy variable for $\lambda_{1, t}^{*}$.

$\lambda_{2, t}^{*}$ being the shadow value of agricultural land unit, we use agricultural value added $\left(a g r v_{t}\right)$ as a proxy to capture this variable.

Agricultural yield especially cereal yield $\left(c r y d_{t}\right)$ is used as a proxy for the gain associated to farm land reconversion $\theta_{t}^{*}$. We suppose that the rate of reconversion of agricultural surface is positively correlated to cereal yield. We also use the square of this variable $\left(\operatorname{cryd} 2_{t}\right)$ to test for linear relationship.

The private marginal cost of farmland exploitation is captured by agricultural value added per worker $\left(a g r w_{t}\right)$ as a proxy for agricultural wage variable since the mechanization still low in the sector and the activity is mainly manual (Blein et al., 2008). 
To capture the level of the technological progress in agricultural sector, we use the average number of machine used in that sector $\left(\right.$ tech $\left._{t}\right)$.

All these variables are on annual basis. The econometric specification of the model is as follows.

$$
\operatorname{agrs}_{t}=\delta_{0}+\delta_{1} r w d_{t}+\delta_{2} a g r v_{t}+\delta_{3} c r y d_{t}+\delta_{4} c r y d 2_{t}+\delta_{5} a g r w_{t}+\delta_{6} t e c h_{t}+\varepsilon_{t}
$$

where $\varepsilon_{t}$ is the error term.

To easily interpret the results and also to stabilise and normalise the possible random errors, we specified the model in double-logarithmic form. Therefore, we took the logarithm of all variables used in the present study.

$$
\begin{aligned}
& \operatorname{lnagrs}_{t}=\gamma_{0}+\gamma_{1} \text { lnrwd }_{t}+\gamma_{2} \text { lnagrv }_{t}+\gamma_{3} \operatorname{lncryd}_{t}+\gamma_{4}\left(\text { lncryd }_{t}\right)^{2}+\gamma_{5} \text { lnagrw }_{t}+ \\
& \gamma_{6} \text { lntech }_{t}+\epsilon_{t}
\end{aligned}
$$

The elasticity measure associated to agricultural yield $\left(e_{\text {cryd }}\right)$ is obtained from the following expression:

$$
e_{\text {cryd }}=\gamma_{3}+2 \gamma_{4} \ln \left(\text { cryd }_{t}\right)
$$

\subsubsection{Data Source and Tests}

The study used secondary data for regression analysis. The sample consisted of annual data covering the period between 1961 and 2003. Data were obtained from World Development Indicator (WDI) CD-ROM 2008 of the World Bank. The descriptive statistics of the variables are presented in table 1 .

Table 1. Descriptive statistics of the variables used in the regression analysis

\begin{tabular}{|l|l|l|l|l|l|l|}
\hline & $\begin{array}{l}\text { Agricultural } \\
\text { surface in ha } \\
\text { (Agrs) }\end{array}$ & $\begin{array}{l}\text { Agricultural } \\
\text { wage in Fcfa } \\
\text { (Agrw) }\end{array}$ & $\begin{array}{l}\text { Agricultural } \\
\text { value added in } \\
\text { Fcfa } \\
\text { (Agrv) }\end{array}$ & $\begin{array}{l}\text { Number of } \\
\text { tractors per } \\
100 \text { ha } \\
\text { (Tech) }\end{array}$ & $\begin{array}{l}\text { Cereal } \\
\text { yield in } \\
\text { Kg/ha } \\
\text { (Cryd) }\end{array}$ & $\begin{array}{l}\text { Roundwood } \\
\text { export in cubic } \\
\text { meter } \\
\text { (Rwd) }\end{array}$ \\
\hline Mean & 177874.9 & 651.0532 & $7.42 \mathrm{E}+11$ & 11.20215 & 953.9116 & 1556151. \\
\hline Median & 174900.0 & 643.6822 & $6.00 \mathrm{E}+11$ & 12.66667 & 880.0000 & 1478000. \\
\hline Maximum & 199000.0 & 805.9074 & $2.05 \mathrm{E}+12$ & 15.82915 & 1540.600 & 3497000. \\
\hline Minimum & 156800.0 & 498.5697 & $7.04 \mathrm{E}+10$ & 0.464286 & 624.2000 & 65971.00 \\
\hline Std. Dev & 14683.77 & 71.52345 & $6.29 \mathrm{E}+11$ & 4.229111 & 227.4007 & 1205927. \\
\hline observations & 43 & 43 & 43 & 43 & 43 & 43 \\
\hline
\end{tabular}

Source: Author 
The econometric regression is done using Eviews software version 6.

$\checkmark$ Time series data analysis

The time series data considered in this study are based on the fundamental assumption that requires the series to be stationary in order to yield reliable results of the relationship between the variables. The study applies the ordinary least squares (OLS) estimation techniques and tests for stationarity and cointegration. This implies a test of the order of integration of the series and the verification of the long run equilibrium relationship between variables. Individual series were tested through a unit root test using the Augmented Dickey-Fuller statistics (ADF). The results are presented in table 2 .

Table 2. Results of unit Root test of stationarity

\begin{tabular}{|l|l|l|l|l|l|l|}
\hline \multicolumn{3}{|c|}{ ADF-LEVELS $(\log )$} & \multicolumn{1}{|c|}{ DF-DIFFERENCES } \\
\hline variables & ADF-t & lag & order & ADF-t & lag & Order \\
\hline Agrs & -1.041236 & 1 & NST & -5.325374 & 1 & ST \\
\hline Agrw & -1.992500 & 1 & NST & -8.737836 & 1 & ST \\
\hline Agrv & -0.905675 & 1 & NST & -5.699122 & 1 & ST \\
\hline Tech & -8.746736 & 1 & I $(0)$ & - & - & - \\
\hline Cryd & -2.695927 & 1 & NST & -7.799087 & 1 & ST \\
\hline Rwd & -2.466433 & 1 & NST & -5.584350 & 1 & ST \\
\hline
\end{tabular}

(1) NST=non stationary in level, ST= stationary after first difference, $\mathrm{I}(0)=$ stationary in level

(2) ADF with an intercept and a linear trend

Source: Author

All variables are $I(1)$ except tech variable which is $I(0)$. That is, they are stationary at first difference. It should be acknowledged that the long run properties of the variables are lost when the variables are differenced. To test for the long run relationship between the variables we apply the Engle-Granger (1987) two steps cointegration test, which uses the residuals from the long run equation estimated with the non stationary variables and then test for the existence of a unit root in the residuals using the ADF. The series are cointegrated if the residual is stationary. It is the case in this study. The results revealed that long run equilibrium relationships exist between agricultural surface (forest land converted to agriculture), rounwood export (forgone competing land use return), agricultural value added (agricultural land value), cereal yield (agricultural land reconversion gain), agricultural wage rate (marginal cost of agricultural exploitation), and the number of agricultural machine (technological progress). As expected the coefficient of the error correction term ECT(-1) has negative sign and more importantly, it is statistically significant at five percent level. This confirms the appropriateness of the error correction approach framework and that ignoring the long run equilibrium relationship is detrimental.

\section{$\checkmark$ Diagnostic tests (post estimation tests)}

The equation is tested for serial correlation, mis-specification errors and heteroscedasticity 
using the breusch-godfrey serial correlation, Ramsey's reset functional form mis-specification, and the autoregressive conditional heteroskedasticity (ARCH) LM tests. The probability values show the absence of autocorrelation and heteroskedasticity as well as mis-specification.

\section{Results and Discussion}

We present successively the short and long run relationships.

\subsection{Cointegration Regression (Static Regression Or Long Run Equilibrium)}

We present the long run equilibrium relationship in table 3. The diagnostic statistics show that the model explains large proportion of the variations in agricultural surface. The adjusted $\mathrm{R}^{2}$ is about 0.98 . The degree of fit is satisfactory. Further, the explanatory variables are almost important determinants of agricultural land demand as implied from F-statistic. The Durbin-Watson statistic is about two, thus the model does not suffer from problems of auto-correlation.

Table 3. Long run equilibrium relationship

\begin{tabular}{|c|c|c|c|c|}
\hline $\begin{array}{l}\text { Dependent Variable: } \\
\text { Method: } \\
\text { Sample: } \\
\text { Included observations: }\end{array}$ & & $\begin{array}{l}\text { Ln(agrs) } \\
\text { Least Sq } \\
1961 \text { to } 2 \\
43\end{array}$ & & \\
\hline Variable & Coefficient & Std. Error & t-Statistic & Prob. \\
\hline $\mathrm{C}$ & $7.175072 * * *$ & 2.433349 & 2.948641 & 0.0056 \\
\hline $\operatorname{Ln}($ agrw) & $-0.036569 *$ & 0.021486 & -1.701981 & 0.0974 \\
\hline Ln(agrv) & $0.047953 * * *$ & 0.005163 & 9.288191 & 0.0000 \\
\hline $\operatorname{Ln}($ tech $)$ & 0.006760 & 0.006613 & 1.022243 & 0.3135 \\
\hline Lncryd2 & $-0.087269 *$ & 0.048817 & -1.787672 & 0.0822 \\
\hline $\operatorname{Ln}($ cryd $)$ & $1.209304 *$ & 0.676475 & 1.787656 & 0.0823 \\
\hline $\operatorname{Ln}(\mathrm{rwd})$ & $-0.024780 * * *$ & 0.003766 & -6.580606 & 0.0000 \\
\hline R-squared & 0.983711 & \multicolumn{2}{|c|}{ Mean dependent var } & 12.08552 \\
\hline Adjusted R-squared & 0.980996 & \multicolumn{2}{|c|}{ S.D. dependent var } & 0.082408 \\
\hline S.E. of regression & 0.011360 & \multicolumn{2}{|c|}{ Akaike info criterion } & -5.969475 \\
\hline Sum squared resid & 0.004646 & \multicolumn{2}{|c|}{ Schwarz criterion } & -5.682768 \\
\hline Log likelihood & 135.3437 & \multicolumn{2}{|c|}{ Hannan-Quinn criter. } & -5.863746 \\
\hline F-statistic & 362.3416 & \multicolumn{2}{|c|}{ Durbin-Watson stat } & 0.743649 \\
\hline Prob(F-statistic) & 0.000000 & & & \\
\hline
\end{tabular}

*significant at $10 \% * * *$ significant at $1 \%$

Source: Author from WDI 2008

The coefficient of rwd is negative (expected sign) and statistically significant at five percent level. As opportunity cost of converting forest land to agriculture (timber production) increases, agricultural surface tends to fall. This result is supported by Sharma (1994). In other words, an alternative use of forest land especially for timber exploitation is likely to reduce deforestation. One possible explanation of this result is that forest concession regulation states that every 150 
or 250 cubic meters exploited for timber must be compensated by a reforestation of one hectare. This kind of regulation does not exist in agricultural sector.

As expected, the value of agricultural land has positive sign and is statistically significant. That is, forest land conversion to agriculture rises with its value. In other words, a rise in agricultural profitability tends to accelerate forest land conversion to agriculture. Farmers are market oriented decision makers since they response to market incentives. These findings are in line with the ones obtained by Osei Asare \& Obeng Asiedu (2000), Barbier (2000/2004) and Gbetnkom, D. (2007).

Although, it is not significant (the agricultural sector is less mechanized), the technological progress does not have the expected sign. It is positive showing that forest land conversion to agriculture increases with technological progress as showing by Morton et al. (2006) and Vandermeer \& Perfecto (2007) in contrast to the phenomenon of land-sparing supported by some studies (Meyfroidt \& Lambin, 2007; Ewers et al., 2009). Probably, the current technology in use in agricultural sector is less intensive in labour. Indeed, the labour intensive technology will tend to reduce deforestation (forest land conversion) through two mechanisms. Firstly, if the technology is intensive in labour, then there are no more workers available for one more hectare of exploitation. Therefore, agricultural land could not be extended. Secondly, the scarcity of labour will raise the wage rate that will result in forest preservation. Therefore, technologies that are labour-intensive can significantly slowdown forest land conversion in line with subsistence hypothesis and is consistent with the findings of Arild Angelsen \& Kaimowitz (2001) and Delacote (2009).

The reconversion rate of agricultural surface shows a non-linear (quadratic) relationship. As cereal yield is a proxy for the rate of reconversion, we can say that there is a minimum level of cereal yield required to reduce farmland expansion supporting the Borlaug hypothesis (Balmford et al., 2005; Mattison \& Norris, 2005; Matson \& Vitousek, 2006; Burney et al., 2010) and rejecting Jevons paradox found by some authors (Rudel et al., 2009; Lambin \& Meyfroidt, 2011). From the elasticity equation (32), the minimum level of cereal yield is $967.1 \mathrm{~kg} / \mathrm{hectare}$ while the average yield value is about $953.9 \mathrm{~kg} / \mathrm{hectare}$ with some low level reaching even $624.2 \mathrm{~kg} / \mathrm{ha}$. As long as the minimum level required is not satisfied, any increase in agricultural production will result in more deforestation.

As expected, marginal cost of agricultural exploitation has a negative and significant impact on forest land conversion. As marginal cost of agricultural exploitation rises, forest land conversion to agriculture decreases. These results confirm earlier findings (Osei Asare \& Obeng Asiedu 2000; Geist \& Lambin, 2002; Shandra et al., 2008; Delacote, 2009). This can be the case if there are some off farm activities. Indeed, this situation will tend to raise the wage rate and then result in less forest land conversion since agricultural profitability has become low.

\subsection{Short Run Dynamic}

The results in short run are presented in table 4.

As expected the coefficient of the error correction term ECT(-1) has negative sign and more 
importantly, it is statistically significant at five percent level. This confirms the appropriateness of the error correction approach framework. Its coefficient shows that about $17 \%$ of the disequilibrium between short and long run value of forest land conversion to agriculture is corrected in each period compared to the previous or next period.

As shown in the table 4, in short run, only three variables are significant in explaining forest land conversion growth. Agricultural value land growth and the growth rate of reconversion of farm land positively affect forest land conversion to agriculture in short run.

However, the growth of marginal cost of exploitation negatively affects the growth rate of forest land conversion to agriculture.

Table 4. Short run dynamic (error correction model)

\begin{tabular}{|c|c|c|c|c|}
\hline Dependent Variable: & & \multicolumn{3}{|c|}{ DLOG(agrs) } \\
\hline Method: & & & \multicolumn{2}{|c|}{ Least Squares } \\
\hline Sample (adjusted): & & & \multicolumn{2}{|c|}{1962 to 2003} \\
\hline Included observations & & & \multicolumn{2}{|c|}{42 after adjustments } \\
\hline Variable & Coefficient & Std. Error & t-Statistic & Prob. \\
\hline $\mathrm{C}$ & $0.003997 * * *$ & 0.001073 & 3.725076 & 0.0007 \\
\hline Dln(agrw) & $-0.032900 * * *$ & 0.011695 & -2.813291 & 0.0081 \\
\hline Dln(agrv) & $0.019745^{* *}$ & 0.008803 & 2.242858 & 0.0315 \\
\hline Dln(tech) & -0.001830 & 0.003821 & -0.478895 & 0.6351 \\
\hline Dlncryd2 & -0.035887 & 0.021755 & -1.649597 & 0.1082 \\
\hline $\operatorname{Dln}($ cryd $)$ & $0.510446 *$ & 0.299158 & 1.706277 & 0.0971 \\
\hline $\mathrm{Dln}(\mathrm{rwd})$ & -0.002808 & 0.002612 & -1.074931 & 0.2900 \\
\hline ECT(-1) & $-0.175624 * *$ & 0.080913 & -2.170515 & 0.0370 \\
\hline R-squared & 0.374719 & \multicolumn{2}{|c|}{ Mean dependent var } & 0.005675 \\
\hline Adjusted R-squared & 0.245985 & \multicolumn{2}{|c|}{ S.D. dependent var } & 0.005381 \\
\hline S.E. of regression & 0.004672 & \multicolumn{2}{|c|}{ Akaike info criterion } & -7.724647 \\
\hline Sum squared resid & 0.000742 & \multicolumn{2}{|c|}{ Schwarz criterion } & -7.393663 \\
\hline Log likelihood & 170.2176 & \multicolumn{2}{|c|}{ Hannan-Quinn criter. } & -7.603328 \\
\hline F-statistic & 2.910792 & \multicolumn{2}{|c|}{ Durbin-Watson stat } & 1.602950 \\
\hline Prob(F-statistic) & 0.016958 & & & \\
\hline
\end{tabular}

$*$ significant at $10 \% \quad * *$ significant at $5 \% \quad * * *$ significant at $1 \%$

Source: Author from WDI 2008

\section{Conclusion}

Deforestation threatens Ivorian economy in the sense that it negatively affects agricultural production on which it depends. Indeed, the shifting characteristic of Ivorian agriculture explains that any increase in its production is not due to the productivity gain but to an increase in crop land and the number of agricultural workers. This situation gives us incentives to investigate the optimal forest land conversion mechanisms. To this end, we firstly established 
the optimal rule of forest land allocation to agriculture based on a rigorous forest land use modelling by using optimal control techniques. We retained four different land use options including timber exploitation, reforestation, forest preservation, and agriculture. The resolution of the theoretical model pointed up various factors explaining forest land conversion like opportunity cost of converting forest land to agriculture, the cost of exploitation, the rate of reconversion of agricultural surface, and the shadow value of farm land. On this basis, we secondly, set up an econometric model to evaluate the effects of these variables on optimal forest land conversion to agriculture in the form of agricultural land demand. Due to the non stationarity of the time series variables at level, we resort to an error correction model. Therefore, we perform short and long run regressions. The main results are that the opportunity cost of forest land and the marginal cost of agricultural exploitation preserve the forest by limiting forest land conversion to agriculture. However, a technological progress in agricultural sector amplifies land conversion process but it is not significant. This suggests that these technologies are less intensive in labour/capital. The insignificancy of this variable can be explained by the weakness of agricultural technology adoption. Finally, we found that there is a minimum level of agricultural reconversion rate required to reduce forest land conversion. Thus, the paper recommends a diversification of Ivorian economy (off farm activities development), an increase in agricultural yield and the adoption of labour/capital intensive technologies to fight against deforestation and guarantee the economic growth in order to achieve a sustainable development.

\section{References}

Adu G., Marbuah, G., \& Mensah, J. T. (2012). Contribution of Agriculture to Deforestation in the Tropics: A theoretical Investigation. African Review of Economics and Finance, 3(2), 1-12.

Alston, L. J., Libecap, G. D., \& Mueller, B. (2000). Land Reform Policies, the Sources of Violent Conflict, and Implications for Deforestation in the Brazilian Amazon. Journal of Environmental Economics and Management, 39(2), 162-88. http://dx.doi.org/10.1006/jeem.1999.1103

Alston, Lee J., Gary D. Libecap, \& Bernardo Mueller. (1999). Conflicts, and Land Use: The Development of Property Rights and Land Reform in the Brazilian Amazon Frontier. Ann Arbor: University of Michigan Press. PMCid:2144408.

Angelsen A., \& Kaimowitz, D. (2001). Agricultural Technologies and Tropical Deforestation. New York: CABI Publishing in Association with CIFOR. http://dx.doi.org/10.1079/9780851994512.0000

Angelsen, A. (1999). Agricultural Expansion and Deforestation: Modelling the Impact of Population, Market Forces, and Property Rights. Journal of Development Economics, 58, 185-218. http://dx.doi.org/10.1016/S0304-3878(98)00108-4.

Angelsen, A., Shitindi, E. C. K., \& Aarrestad, J. (1999). Why do farmers expand their land into forests?: Theories and evidence from Tanzania. Environment and Development Economics, 4, 313-331. http://dx.doi.org/10.1017/S1355770X99000212 
Arcand, J. L., Guillaumont, P., \& Jeanneney, S. G. (2008). Deforestation and the real exchange rate. Journal of Development Economics, 86(2), 242-262. http://dx.doi.org/10.1016/j.jdeveco.2007.02.004

Balmford, A., Green, R. E., \& Scharlemann, J. P. W. (2005). Sparing land for nature: exploring the potential impact of changes in agricultural yield on the area needed for crop production. Global Change Biology, 11, 1594-1605. http://dx.doi.org/10.1111/j.1365-2486.2005.001035.x

Barbier, E. B. (1997). The Economic Determinants of Land Degradation in Developing Countries. Philosophical Transactions of the Royal Society, Series B 352(1356), 891-99. http://dx.doi.org/10.1098/rstb.1997.0068. PMCid:1691978

Barbier, E. B. (2000). Institutional Constraints and Deforestation. Paper presented at the 2000 Royal Economic Society/Scottish Economic Society Conference, St Andrews, Scotland, July 10-13, 2000.

Barbier, E. B. (2001). The Economics of Tropical Deforestation and Land Use: An Introduction to the Special Issue. Land Economics, 77(2), 155-171. http://dx.doi.org/10.2307/3147087

Barbier, E. B. (2004). Explaining Agricultural Land Expansion and Deforestation in Developing Countries. American Journal of Agricultural Economics, 86(5), 1347-1353. http://dx.doi.org/10.1111/j.0002-9092.2004.00688.x

Barbier, E. B., \& Burgess, J. C. (1996). Economic Analysis of Deforestation in Mexico. Environment and Development Economics, 1(2), 203-40. http://dx.doi.org/10.1017/S1355770X00000590

Barbier, E. B., \& Burgess J. C. (1997). The Economics of Tropical Forest Land Use Options. Land Economics, 73, 174-95. http://dx.doi.org/10.2307/3147281

Bashaasha, B., Kraybill, D. S., \& Southgate, D. D. (2001). Land Use Impacts of Agricultural Intensification and Fuelwood Taxation in Uganda. Land Economics, 77(2), 241-249. http://dx.doi.org/10.2307/3147092

Benhin, J. K. A. (2006). Agriculture and Deforestation in the Tropics: A Critical Theoretical and Empirical Review. Ambio, 35, 9-16. PMid:16615693

Blein R., B. G. Soulé, B. F. Dupaigre, \& B. Yérima (2008), Les Potentialités Agricoles de l'Afrique de l'Ouest (CEDEAO), Fondation pour l'Agriculture et la Ruralité dans le Monde (FARM), Paris, France. PMCid:2525531. Website: www.fondation-farm.org (March, 4, 2013)

Burgess, Joanne C. (2000). The Economics of Tropical Forest Land Use. Ph.D. dissertation, Economics Department, University College London.

Burney, J. A., Davis, S. J., \& Lobell, D. B. (2010). Greenhouse gas mitigation by agricultural intensification. Proceedings of the National Academy of Sciences USA, 107(26), 12052-12057. http://dx.doi.org/10.1073/pnas.0914216107. PMid:20551223 PMCid:2900707.

Brandon, C., \& Ramankutty, R. (1993). Toward an Environmental Strategy for Asia. World 
Bank Discussion Paper No. 224. Washington: The World Bank

Carter, B., \& Ramankutty, R. (1993). Toward an Environmental Strategy for Asia. World Bank Discussion Paper, 224. Washington, D.C.: World Bank. http://dx.doi.org/10.1596/0-8213-2737-2

Cattaneo, A. (2001). Deforestation in the Brazilian Amazone: Comparing the impacts of macroeconomic shocks, land tenure, and technological change. Land Economics, 77(2), 219-240. http://dx.doi.org/10.2307/3147091

Chomitz, K. M., \& Gray, D. P. (1996). Roads, Land Markets, and Deforestation: A Spatial Model of Land Use in Belize. The World Bank Economic Review, 10(3), 487- 512. http://dx.doi.org/10.1093/wber/10.3.487

Coulibaly, N. (1998). Déforestation et Activités Agricoles en Côte d'Ivoire: Recherche d'un nouvel équilibre. Thèse de doctorat, Université Laval, Québec.

Cropper, M., Griffiths, C., \& Mani, M. k. (1999). Roads, Population Pressures, and Deforestation in Thailand, 1976-1989. Land Economics, 75, 58-73. http://dx.doi.org/10.2307/3146993

Damette, O., \& Delacote, P. (2012). On the economic factors of deforestation: What can we learn from quantile analysis? Economic Modelling, 29(6), 2427-2434. http://dx.doi.org/10.1016/j.econmod.2012.06.015

Deacon, R. T. (1994). Deforestation and the Rule of Law in a Cross-Section of Countries. Land Economics, 70, 414-430. http://dx.doi.org/10.2307/3146638

Deacon, R. T. (1999). Deforestation and Ownership: Evidence from Historical Accounts and Contemporary Data. Land Economics, 75, 341-359. http://dx.doi.org/10.2307/3147182

Delacote, P. (2009). Déforestation tropicale: Enjeux et politiques. Cahiers $d u$ LEF , n ${ }^{\circ}$ 2009-05

Ehui, S. K., \& Hertel, T. (1989). Deforestation and Agricultural Productivity in the Côte d'lvoire. American Journal of Agricultural Economics, 71, 703-711. http://dx.doi.org/10.2307/1242026

Ehui, S., Hertel, T., \& Preckel, P. (1990). Forest Resource Depletion. Soil Dynamics and Agricultural Productivity in the Tropic. Journal of Environmental Economics and Management, 18, 136-154. http://dx.doi.org/10.1016/0095-0696(90)90044-Y

Engle, R. F., \& Ganger, C. W. J. (1987). Cointegration and error correction representation, estimation and testing. Econometrica, 55(2), 251-276. http://dx.doi.org/10.2307/1913236

Ewers, R. M., Scharlemann, J. P. W., Balmford, A. \& Green, R. E. (2009). Do increase in agricultural yield spare land for nature? Global Change Biology, 15(7), 1716-1726. http://dx.doi.org/10.1111/j.1365-2486.2009.01849.x

FOSA (2001). Rapport annuel Afrique de l'Ouest. Forest Outlook Study for Africa.

Gbetnkom, D. (2007). Forest management, gender and food security of the rural poor in Africa. 
Research Paper, UNU-WIDER, United Nations University (UNU), N. 2007/86, ISBN 978-92-9230-039-5.

Gbetnkom, D. (2009). Forest Depletion and Food Security of Poor Rural Populations in Africa: Evidence from Cameroon. Journal of African Economies, 18(2), 261-286. http://dx.doi.org/10.1093/jae/ejn012

Gibbs, H. K., Ruesch, A. S., Achard, F., Clayton, M. K., Holmgren, P., Ramankutty, N., \& Foley, J. A. (2010). Tropical forests were the primary sources of new agricultural land in the 1980s and 1990s. Proceedings of the National Academy of Sciences USA, 107(38), 16732-16737. http://dx.doi.org/10.1073/pnas.0910275107. PMid:20807750 PMCid:2944736.

Giest, H. J., \& Lambin, E. F. (2002). Proximate causes and underlying driving forces of tropical $\begin{array}{llr}\text { deforestation. } & \text { Bioscience, } & \text { 143-150. }\end{array}$ http://dx.doi.org/10.1641/0006-3568(2002)052[0143:PCAUDF]2.0.CO;2

Grau, H. R., Gasparri, N. I., \& Aide, T. M. (2008). Balancing food production and nature conservation in the Neotropical dry forests of northern Argentina. Global Change Biology, 14, 985-997. http://dx.doi.org/10.1111/j.1365-2486.2008.01554.x

Kaimowitz, D., \& Angelsen, A. (1998). Economic Models of Tropical Deforestation: A Review. Center for International Forestry Research. Bogor, Indonesia.

Karsenty, A., \& Maitre, H. F. (1994). L'Exploitation et la Gestion Durable des Forêts Tropicales. Bois et Forêts des Tropiques, 240, 37-51.

Koné, A. (1992). Demande de charbon de bois à Abidjan. Thèse de doctorat troisième cycle. Abidjan, Côte d'Ivoire: Université de Cocody-Abidjan.

Lambin, E. F., \& Meyfroidt, P. (2011). Global land use change, economic globalization, and the looming land scarcity. Proceedings of the National Academy of Sciences, 108, 3465-3472. http://dx.doi.org/10.1073/pnas.1100480108. PMid:21321211. PMCid:3048112.

Lopez, R. (1997). Environmental Externalities in Traditional Agriculture and the Impact of Trade Liberalization: The Case of Ghana. Journal of Development Economics, 53, 17-39. http://dx.doi.org/10.1016/S0304-3878(97)00015-1

Matson, P.A., \& Vitousek, P. M. (2006). Agricultural intensification: will land spared from farming be land spared for nature? Conservation Biology, 20, 709-710 http://dx.doi.org/10.1111/j.1523-1739.2006.00442.x. PMid:16909562

Mattison, E. H. A., \& Norris, K. (2005). Bridging the Gap between Agricultural Policy, Land Use and Biodiversity. Trends in Ecology and Evolution, 20, 610-616. http://dx.doi.org/10.1016/j.tree.2005.08.011. PMid:16701444

Mercier, J. R. (1991). La Déforestation en Afrique: Situation et Perspectives. Paris, France: Edisud.

Meyfroidt, P., \& Lambin, E. F. (2007). The causes of reforestation in Vietnam. Land Use Policy, 25, 189-207. 
MINEF. (2007). La Côte d'Ivoire en chiffres. Abidjan, Côte d'Ivoire : Dialogue production.

Morton, D. C, DeFries, R., Shimabukuro, Y. E., Anderson, L. O., Arai, E., Espirito-Santo, F. D. B., Freitas, R., \& Morisette , J. (2006). Cropland expansion changes deforestation dynamics in the southern Brazilian Amazon. Proceedings of the National Academy of Sciences USA, 103, 14637-14641. http://dx.doi.org/10.1073/pnas.0606377103. PMid:16973742 PMCid:1600012.

Nelson, G. C., \& Hellerstein, D. (1997). Do Roads Cause Deforestation? Using Satellite Images in Econometric Analysis of Land Use. American Journal of Agricultural Economics, 79(2), 80-88. http://dx.doi.org/10.2307/1243944

Osei, A., \& Asiedu, O. (2000). The immediate cause of deforestation: the case of Ghana. Beijer Research Seminar.

Pender, J., Nkonya, E., Jagger, P., Sserunkuuma, D., \& Ssali, H. (2003). Strategies to Increase Agricultural Productivity and Reduce Land Degradation: Evidence from Uganda. Paper presented at the 25th International Conference of Agricultural Economists, August 16-22, 2003, Durban, South Africa. PMCid:372252.

Perman R., Common, M., Mcqilvray, J., \& Ma, Y., (2003). Natural Resource and Environmental Economics (3rd Ed.). Boston: Addison Wesley.

Phalan B., Bertzky, M., Butchart, S. H. M., Donald, P. F., Scharlemann, J. P. W., Stattersfield, A. J., \& Balmford, A. (2013). Crop Expansion and Conservation Priorities in Tropical Countries. PLoS Onem, 8(1), e51759. http://dx.doi.org/10.1371/journal.pone.0051759

Reed, D. (1992). Structural Adjustment and the environment. In M. Munasingh (Eds), Environmental impacts of Macroeconomics and sectoral policies. Washington: ISEE/WBI/UNEP

Ricardo, G., Jacobson, M., De Castro, J., Aliago, V., Romero, J., \& Davis, A. (1998). The Role of Tenure Security and Private Time Preference in Neotropical Deforestation. Land Economics, 74, 162-170. http://dx.doi.org/10.2307/3147048

Rudel, T. K., Schneider, L., Uriarte, M., Turner II, B. L., DeFries, R., Geoghegan, J., Lawrence, D., Geoghegan, J., Hecht, S., Ickowitz, A., Lambin, E. F., Birkenholtz, T., Baptista, S., \& Grau, R. (2009). Agricultural intensification and changes in cultivated areas, 1970-2005. Proceedings of the National Academy of Sciences, 106(49), 20675-20680. http://dx.doi.org/10.1073/pnas.0812540106. PMid:19955435 PMCid:2791618

Shandra, J. M., Shor, E., Maynard, G. \& London, B. (2008). Debt, structural adjustment and deforestation: a cross-national study. Journal of World-Systems Research, 14(1), 1-21.

Sharma, N. P., Rietbergen, S., Heimo, C. R., \& Patel, J. (1994). A Strategy for the Forest Sector in Sub-Saharan Africa. World Bank Technical Paper, 251. Washington, D.C. World Bank.

Vandermeer, J. H., \& Perfecto, I. (2007). The agricultural matrix and a future paradigm for $\begin{array}{llll}\text { conservation. } \quad \text { Conservation } & \text { Biology, 274-277. }\end{array}$ http://dx.doi.org/10.1111/j.1523-1739.2006.00582.x. PMid:17298536 


\section{Ml Macrothink}

Von Braun, J. (2007). When food makes fuel: the promises and challenges of biofuels. Canberra, Australia: Crawford Fund.

West, P., Gibbs, H. K., Monfreda, C., Wagner, J., Barford, C. C., Carpenter, S. R., \& Foley, J. A. (2010). Trading Carbon for food: global comparison of carbon stocks vs. crop yields on agricultural land. Proceedings of the National Academy of Sciences USA 107, 19645-19648. http://dx.doi.org/10.1073/pnas.1011078107. PMid:21041633 PMCid:2993385

World Resource (2000-2001). People and Ecosystems: The Fraying Web of life. Washington: UNDP/UNEP/WRI.

\section{Appendix}

\section{Lagrangean method}

Lagrangean, first and second conditions.

\section{Lagrangean}

$$
\begin{aligned}
& L(.)=\sum_{t=1}^{T} \frac{1}{\left(1+r_{0}\right)^{t-1}}\left[R_{1}\left(x_{1, t}\right)+R_{2}\left(x_{2, t}\right)+R_{3}\left(x_{3, t}\right)-C\left(x_{4, t}\right)\right] \\
& +\sum_{t=1}^{T} \lambda_{1, t}\left[x_{4, t}+x_{3, t}-x_{2, t}-x_{1, t}-w_{t}+w_{t-1}\right]+\lambda_{1,0}\left(w(0)-w_{0}\right) \\
& +\sum_{t=1}^{T} \lambda_{2, t}\left[\alpha_{2} x_{2, t-1}+\alpha_{1} x_{1, t-1}-x_{1, t}\right]+\lambda_{2,0}\left(x_{1,0}(0)-x_{1,0}\right) \\
& +\sum_{t=1}^{T} \lambda_{3, t}\left[x_{4, t-1}+(\beta-1) x_{2, t-1}-x_{3, t}+x_{3, t-1}\right]+\lambda_{3,0}\left(x_{3,0}(0)-x_{3,0}\right) \\
& +\sum_{t=1}^{T} \omega_{t}\left[x_{3, t}-\alpha_{0} w_{t}\right]
\end{aligned}
$$

\section{Necessary Conditions}

We expose respectively the first order conditions, transversality conditions, binding conditions and excluding relations.

Since the programme is concave, the necessary conditions are sufficient for optimality.

$$
\begin{gathered}
\frac{\partial L}{\partial x_{1, t}}=\frac{R_{1}{ }^{J}\left(x_{1, t}\right)}{\left(1+r_{0}\right)^{t-1}}-\lambda_{1, t}-\lambda_{2, t}+\alpha_{1} \lambda_{2, t+1}=0 \quad t=1, \ldots, T-1 \\
\frac{\partial L}{\partial x_{2, t}}=\frac{R_{2}{ }^{l}\left(x_{2, t}\right)}{\left(1+r_{0}\right)^{t-1}}-\lambda_{1, t}+\alpha_{2} \lambda_{2, t+1}-(1-\beta) \lambda_{3, t+1}=0 \quad t=1, \ldots, T-1
\end{gathered}
$$




$$
\begin{aligned}
& \frac{\partial L}{\partial x_{\mathrm{a}, t}}=\frac{R_{\mathrm{g}}{ }^{\prime}\left(x_{\mathrm{a}, t}\right)}{\left(1+r_{\mathrm{a}}\right)^{t-1}}+\lambda_{1, t}-\lambda_{3, t}+\lambda_{3, t+1}+\omega_{t}=0 \quad t=1, \ldots, T-1 \\
& \frac{\partial L}{\partial x_{4, t}}=\frac{-c^{\prime}\left(x_{4}\right)}{\left(1+r_{0}\right)^{t-1}}+\lambda_{1, t}+\lambda_{3, t+1}=0 \quad t=1, \ldots, T-1 \\
& \lambda_{1, t+1}-\lambda_{1, t}=\lambda_{1, t}-\lambda_{1, t+1}+\alpha_{0} \omega_{t} \quad t=1, \ldots, T-1 \\
& \lambda_{2, t+1}-\lambda_{2, t}=\lambda_{2, t}-\alpha_{1} \lambda_{2, t+1}-\frac{R_{1}{ }^{\prime}\left(x_{1, t}\right)}{\left(1+r_{0}\right)^{t-1}}-\lambda_{1, t} \quad t=1, \ldots, T-1 \\
& \lambda_{3, t+1}-\lambda_{3, t}=\lambda_{3, t}-\lambda_{3, t+1}-\frac{R_{s}{ }^{\prime}\left(x_{3, t}\right)}{\left(1+r_{0}\right)^{t-1}}-\lambda_{1, t}-\omega_{t}, \quad t=1, \ldots, T-1 \\
& \frac{\partial L}{\partial \lambda_{1, t}}=x_{4, t}+x_{3, t}-x_{2, t}-x_{1, t}-w_{t}+w_{t-1}=0 \quad t=1, \ldots, T-1 \\
& \frac{\partial L}{\partial \lambda_{2, t}}=\left[\alpha_{2} x_{2, t-1}+\alpha_{1} x_{1, t-1}-x_{1, t}\right]=0 \quad t=1, \ldots, T-1 \\
& \frac{\partial L}{\partial \lambda_{\mathrm{B}, t}}=x_{4, t-1}+(\beta-1) x_{2, t-1}-x_{3, t}+x_{3, t-1}=0 \quad t=1, \ldots, T-1
\end{aligned}
$$

Initial Conditions

$$
\begin{aligned}
& \frac{\partial L}{\partial w_{0}}=\lambda_{1,1}-\lambda_{1,0}=0 \\
& \frac{\partial L}{\partial x_{1,0}}=\alpha_{1} \lambda_{2,1}-\lambda_{2,0}=0 \\
& \frac{\partial L}{\partial x_{x_{3} 0}}=\lambda_{3,1}-\lambda_{3,0}=0
\end{aligned}
$$

Transversality Conditions

$\lambda_{1, T+1}^{*} \geq 0, \lambda_{2, T+1}^{*} \geq 0, \lambda_{3, T+1}^{*} \geq 0$ et $\lambda_{1, T+1}^{*} w_{T}^{*}=0, \lambda_{2, T+1}^{*} x_{1, T}^{*}=0, \lambda_{3, T+1}^{*} x_{3, T}^{*}=0$

Excluding relations

$$
\omega_{t}\left[x_{3, t}-\alpha_{0} w_{t}\right]=0
$$




$$
\begin{aligned}
& \text { If } \left.\omega_{t}=0, x_{3, t} \geq \alpha_{0} w_{t}\right] \\
& \text { If } \left.\omega_{t}>0, x_{3, t}=\alpha_{0} w_{t}\right]
\end{aligned}
$$

\section{Copyright Disclaimer}

Copyright reserved by the author(s).

This article is an open-access article distributed under the terms and conditions of the Creative Commons Attribution license (http://creativecommons.org/licenses/by/3.0/). 